\title{
VOX REDACTORIS
}

\section{RELIGIOUS VECTOR IN RUSSIAN HISTORY AND THE STEREOTYPES OF CULTURAL IMAGERY}

\author{
The spiritual influence of Reverend Sergiy has long outlasted his earthly \\ existence and his name has gone from historical \\ memory to an eternally active moral engine, becoming a part of the \\ spiritual vitality of the people.
}

V. O. Klyuchevsky

Defining the themes for Quaestio Rossica in 2014, the Editorial Board could not possibly leave aside the anniversary of St. Sergiy Radonezhsky. The attitude of $19^{\text {th }}$-century historians to this outstanding figure is perhaps best expressed in the words of Vasily Klyuchevsky, quoted in the epigraph. The country has since changed; the Russian Orthodox Church, which went through severe trials, managed to survive and in the process rebuilt its institutions throughout Russia.

This new edition may not offer a comprehensive answer as to whether or not modern researchers' perception of St. Sergiy Radonezhsky has changed. Indeed we will need to return to it. Nevertheless, the articles assembled in this issue offer a tribute to St. Sergiy as a historical figure and writer, and they provide substantial evidence that the history of the Orthodox Church is an important topic in modern academic discourse, both in Russia and abroad.

The 'Problema Volumnis' Section ('Sergiy Radonezhsky and the Russian Religiosity") opens with an article by Vladimir Milkov (Institute of Philosophy of RAS), devoted to St. Sergiy Radonezhsky and his impact on the country's social and political life as it found itself in desperate need of consolidation. In harsh political circumstances, Sergiy envisioned religion as a legitimate basis for the consolidation and formation of a common identity within the country. The Orthodox Church and all its institutions, its ministers and the dogma had to meet their assigned mission, so Sergiy actively implemented monastery reforms and also introduced a novel cult of the Trinity. As a result, the Orthodox Church, similar to the the Church in Europe in its time, played a key role in the process of centralization, and Sergiy was recognized as one of the spiritual leaders of the nation on the eve of the Battle of Kulikovo in national historiography.

Turning from the Church's promising ideas of consolidation, another historical analysis explores the loss of seemingly sustainable concepts. British historian Maureen Perrie (University of Birmingham) emphasizes the little known fact of the rejection of the idea of "Muscovy as the New Israel". This idea lost currency not only through the proscription of Patriarch Nikon but 
also with the Old Believers' negative attitude towards aggrandizing a Russian "New Jerusalem". The rumors about the impending arrival of the Antichrist in Jerusalem in 1666 became the justification for the third and last schism from the true faith after the ones in 1054 and 1596. In the historiography of Russian religious thought, the idea of the correlation between Russia and Israel has not received due reflection; this gap is partly filled by the author's article "Moscow in 1666: New Jerusalem, Third Rome, Third Apostasy".

The eminent role of the Church as an institution during the initial stage of the state's formation has solidified its place in society. Again and again when facing a crisis, much of the state establishment and the general public appealed to the Church as they sought a basis for consolidation, protection of the state and a strengthening of the nation's consciousness.

Since the religious life of the majority of the population is organized and takes place mostly within parish institutions, it is not surprising that many researchers examine this subject. The article by Alexey Beglov (Institute of World History of RAS) considers the activities of the Holy Synod Procurator, K. P. Pobedonostsev, aimed at achieving a compromise between church and secular institutions in organizing, financing and generally sustaining parishes. Based on the analysis of a wide circle of already-known and new sources, the author comes to a probable conclusion that the reform not only remained unfinished, but failed to activate parish life, and, therefore, did not meet the challenges of the time.

Marina Nechayeva's (Institute of History and Archaeology of the Urals Branch of RAS) article studies yet another attempt at strengthening the Church's influence over society, resulting in the formation of public, Orthodox organizations, which occurred from the second half of the $19^{\text {th }}$ through the beginning of the $20^{\text {th }}$ centuries. With the help of the Church's organizations, the author sees an attempt to modernize the country's public life. Analyzing the sources that characterize the interaction between power and communal initiatives in the process of the formation and development of these organizations, as well as public comments on their activities, the researcher concludes convincingly that the existing public Orthodox organizations were a "school of citizenship and social initiative", yet not public organizations in the classic sense of the term. It should be noted that similar institutions were being built approximately at the same time by the Catholic Church in Western Europe. In Europe they indeed became public organizations and proved their ability to unite the religious population within national, religious and secular institutions such as the National Catholic Action in France and Italy, the Catholic trade unions, Catholic youth and student organizations and so on.

Alexander Palkin, a researcher from Ural Federal University, analyzes the phenomenon of Edinoverie, a version of Orthodoxy, which was forcibly implemented by the state and sought to find a compromise between the Old Believers and the official Orthodox Church. Seemingly successful state efforts in conversion of Old Believers to edinoverie did not indicate the attraction of the official church for the Old Believers. Archival material shows a contradictory 
situation, in which edinovercy found themselves in Ural factories where their immediate supervisors (the administrators) were Old Believers.

The article by Irina Paert and Toomas Schvak (University of Tartu, Estonia) focuses on the history of Orthodox education in the Baltic provinces of Russia and later in independent Estonia. History shows that a religious institution gets deeply rooted in any given place only when the transmission of religious knowledge and values occurs across generations. The Orthodox Church sought to solve this particular problem with its system of educational institutions. The authors successfully solve the research problem associated with the analysis of the evolution of Orthodox educational formats in the independent Republic of Estonia from its formation until 1941. The Editorial Board looks forward to continuing the discussion on the fate of Orthodoxy in other independent republics, which were formerly part of the Russian Empire.

One more important theme that the Editorial Board intends to further develop and support in 2015 is the images and the stereotypes of Russia or, rather, Russian originality embodied in images and stereotypes. This embodiment can be seen in artifacts and events that exist for a majority of the population and in stereotypes that are reproduced by the advertising industry and mass media. Scrutiny of this theme seems unavoidable if one hopes to comprehend the unique and the common in the character of Russia.

Quaestio Rossica also includes articles from various fields in the $\mathrm{Hu}-$ manities. The image of Moscow and Muscovites in Russian and other foreign languages is analyzed by Elena Berezovich (Ural Federal University) and her colleague Iulia Krivoshchapova (UrFU Lyceum), who draw upon exhaustive linguistic data.

Unfamiliar to Russian and foreign readers alike, the dramatic works of Dutch authors from the $19^{\text {th }}$ century address the conflict between Peter the Great and his son Alexey, which is examined by Emmanuel Waegemans (Katholieke Universiteit Leuven). We translated the article into Russian, believing that unknown aspects of written culture are important for the Russian-speaking reader. Understanding the history of Russia by authors from the Netherlands gives food for thought about the universal problem of fathers and children, power and the price of it, humanity and justice, which are important for any time, including now.

The stereotypes, which are typical in historical memory and are embodied in the advertising of the alcohol industry in post-Soviet Russia, are discussed in the article by Graham Roberts (University of Paris X - Nanterre). A peculiar echo of religious themes appears in the article by Sergei Goryaev (Ural Federal University) about church-related names of wines. Partially translated, but for the most part created through the imagination of advertising specialists, those names reflect the curious refraction of religious discourse in mass consciousness.

Two similar articles on the history of the manufacturing industry in the Urals appear in the 'Disputatio' Section of this issue of Quaestio Rossica. Attention to manufacturing is no accident for researchers of the region; 
it is exactly the history of the establishment and development of modern technologies in manufacturing, which constitute the essence of the Urals' identity. Yevgeniy Neklyudov (Institute of History and Archaeology, Ural Branch of RAS) shows how the Ural mine owners in the beginning of the $20^{\text {th }}$ century conceptualized the place of their region's industry within the Russian economy and what measures they proposed to promote mining works. The article by Olga Ermakova (Institute of History and Archaeology, Ural Branch of RAS), based on the archival sources and analysis of Russian legislation, looks at the problems associated with the state's strategy to attract foreign specialists to Ural factories. The author also touches upon the downside of protectionism: that is, privileges created a negative attitude within the locals and did not foster a friendly atmosphere.

The Third Issue of Quaestio Rossica for 2014 sees the last part of the philosophic memoir of Daniel Waugh, a prominent American Slavist and Professor Emeritus at the University of Washington (Seattle), which details his work with early Russian manuscripts as well as his meetings with Russian researchers during Soviet and post-Soviet times ('Scientia et vita' Section). This part contains an exciting narrative on his work with an interesting historical manuscript dating back to the $17^{\text {th }}$ century, created in Vyatka (now Kirov); he also describes the harsh destiny of history studies in the Russian province. D. Waugh's article is by itself a historical source on the topic of the international relations of Russian research, which is why, quite naturally, it is published in original and also translated into Russian. The memoirs of the American Slavist quite organically echo the essay on the personality and achievements of the Russian historian, Sergey Mikhailovich Kashtanov, a leading specialist in diplomacy and the medieval history of Russia. If Waugh's orbit of interest is early Russian books and manuscripts, Kashtanov's interests include ancient Russian Acts as sources that reflect the evolution of state institutions and the embodiment of political decisions. The biographical essay, created by the students and adherents of S. M. Kashtanov, L. Stolyarova and J. Koroleva (Institute of World History of RAS), realizes the Editorial Board's mission to identify the lines of development in the Humanities and record the fate of Russian scientists ('Heritage. Nomina et scholae' Section). The article was translated into English to expand the information base for global humanities.

The reviews, which are presented in 'Critica' Section, are quite contrasting in their tone. Sergei Nefedov (Institute of History and Archaeology, Ural Branch of RAS) in his review praises the monograph by G. I. Hanin, a specialist in the economic history of Russia. Despite the fact that the book was published in 2008, the journal decided to draw attention to it, especially in light of today's difficult economic situation. A critical review by Natalia Dyachkova (Missionary Institute, Yekaterinburg) bears the ironic title "Tell a Lie Once, or How We Must Love Russian Language" and describes in detail the errors and fraud in the books of V. Irzabekov about the Russian language. Claiming to perform a noble, patriotic task by awakening love for the Russian language and by showing its spiritual heights, the work, however, dem- 
onstrates linguistic incompetence and negligence for scientific reasoning, thereby superseding any good intentions held by the author.

We certainly hope that Quaestio Rossica attracts the attention of a wider audience of specialists within the Humanities; we eagerly await responses to ideas, communicated in previously published issues.

Editorial Board

Translated by Anna Dergacheva

\title{
РЕЛИГИОЗНЫЙ ВЕКТОР ИСТОРИИ И КУЛЬТУРНО-ОБРАЗНЫЕ СТЕРЕОТИПЫ РОССИИ
}

\begin{abstract}
Духовное влияние преподобного Сергия пережило его земное бытие и перелилось в его имя, которое из исторического воспоминания сделалось вечно деятельным нравственным двигателем и вошло в состав духовного богатства народа.
\end{abstract}

В. О. Ключевский

Определяя тематику журнальных выпусков на 2014 г. ${ }^{1}$, редколлегия Quaestio Rossica не могла обойти вниманием 700-летний юбилей Преподобного Сергия Радонежского ${ }^{2}$. Отношение российского общества XIX в. к этому выдающемуся деятелю, пожалуй, лучше всего выражено в словах В. О. Ключевского, вынесенных в эпиграф. Изменилась страна, тяжелые испытания прошла Русская православная церковь, сумевшая выстоять и восстановить свои институты на территории всей России. Вопрос о том, насколько изменилось понимание деяний Сергия Радонежского и значение его личности как со стороны современных исследователей, так и внутри всего российского общества, вероятно, не получит полного ответа в данном выпуске журнала. Статьи, которые были подготовлены как дань уважения к нему как к исторической личности и духовному лидеру, свидетельство того, что история Православной церкви является важной частью современного научного и общественного дискурса как в России, так и за рубежом.

Раздел «Сергий Радонежский и российская религиозность» (Problema voluminis) открывается статьей Владимира Милькова (Институт философии РАН), посвященной деятельности Сергия Радонежского и его влиянию на общественно-политическую жизнь страны в конце XIV в., отчаянно нуждавшейся в сплочении. В условиях политического кризиса Сергий видел религиозный фактор

${ }^{1}$ Редколлегия Quaestio Rossica придерживается гибкой языковой политики. Ряд статей в этом номере публикуются в переводах, другие на языке оригинала. Публикуя статьи на четырех языках, мы учитываем пожелания автора, наше видение потенциальной аудитории статьи и возможности ее расширения, также преследуется цель укрепления информационной базы мировой русистики.

${ }^{2}$ Cм.: Quaestio Rossica. 2013. № 1. C. 212.

(C) Dergacheva A., 2014 